\title{
АСЕПТИКА I АНТИСЕПТИКА В РОБОТІ МЕДИЧНОЇ СЕСТРИ ХІРУРГІЧНОГО ПРОФІЛЮ
}

\author{
I. I. Романенко \\ КЗ «Шосткинська центральна районна лікарня" \\ ДвНЗ «Тернопільський державний медичний університет \\ імені І. Я. Горбачевського МОЗ Украӥни"
}

У статті розглянуто питання про хірургічну обробку рани, джерела потрапляння мікробів у рану, види прибирання. Висвітлено аспекти хірургічної антисептики рук.

\section{ASEPTICS AND ANTISEPTICS IN THE WORK OF A NURSE OF SURGICAL PROFILE}

\author{
I. I. Romanenko \\ Municipal Institution "Shostka City District Hospital» \\ I. Horbachevsky Ternopil State Medical University
}

The article deals with the question of surgical treatment of the wound, the source of germs into the wound, types of cleaning. The aspects of surgical hand antiseptic are covered.

Вступ. Основний закон хірургії - асептика - вимагає, щоб усе, що контактує з раною, було стерильно, тобто вільним від мікробів. Це стосується різних пункцій, вливань та інструментальних методів дослідження. У цій статті розглянуто такі методи знезараження, як асептика і антисептика. Ці поняття варто розглядати в комплексі заходів, що доповнюють один одного, одне без одного не матиме найкращого результату.

Основна частина. Антисептика - це сукупність лікувально-профілактичних заходів, спрямованих на знищення чи пригнічення життєдіяльності мікроорганізмів у ранах, на шкірі, слизових оболонках і порожнинах із метою лікування й запобігання розвитку інфекційних процесів.

Вирізняють антисептику:

- механічну;

- фізичну;

- біологічну;

- хімічну.

Механічна:

- первинна хірургічна обробка рани;

- вторинна хірургічна обробка рани;

- туалет рани.

Первинну хірургічну обробку рани проводять у перші 12 год після її отримання, коли ще мікроорга-

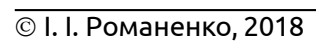

нізми не виходять за межі рани - висіченням країв рани, зупинкою кровотечі, видаленням сторонніх тіл, накладанням швів [1].

Вторинну хірургічну обробку рани проводять у пізні строки після нанесення травми (часто при лікуванні сепсису, коли висікають рану й накладають шви).

Туалет рани:

- обробка пульсуючим струменем антисептика (число мікробів зменшиться на 1-2 порядки);

- вакуумну обробку рани проводять 5-10 хв до появи капілярної кровотечі (у рану наливають розчин антисептичної речовини й відсмоктують);

- ультразвукова обробка (рану промивають розчином антисептичної речовини, дія на неї ультразвуком 3-10 Xв);

- лазерна обробка.

Фізична. Створення несприятливих умов для розвитку і розмноження мікроорганізмів у рані за допомогою фізичних властивостей різних засобів. Її метою є забезпечення доброго відтоку від рани за допомогою:

- серветок, турунд, дренажів, які вводять у рану, при цьому марлеві серветки змочують $10 \%$ розчином хлориду натрію для покращення всмоктування вмісту рани серветкою протягом 12 год;

- ультрафіолетового опромінення рани;

- висушування ран, особливо при опіках. 
Біологічна. Полягає у використанні препаратів, які містять живі мікроорганізми (бактеріофаги), які конкурують із мікроорганізмами в рані. Це колібактерин, лактобактерин сухий, біфікол, бактисубтил) [1].

Хімічна. Передбачає використання різноманітних хімічних речовин для знищення чи затримки розвитку бактерій у рані. Наприклад:

- альдегіди (формальдегід);

- галоїди (йод, йодонат, йодопірон, хлорамін Б, розчин Люголя, хлоразид);

- барвники (брильянтовий зелений, метиленовий синій, риванол);

- кислоти (С-4, дезоксон);

- окиснювачі (перекис водню, калію перманганат);

- солі важких металів (сулема, ляпіс);

- феноли (карболова кислота, лізол);

- нітрофурани (фурацилін, фурадонін, фуразолідон);

- похідні оксихіноліну (хлоргексидину біглюконат, діоксидин);

- представники різних груп (мікроцид, димексид, хлорофіліпт);

- представники групи детергентів [1].

Асептика - комплекс заходів, що спрямовані на запобігання проникненню мікроорганізмів у рану, органи і тканини хворого в процесі будь-яких лікарських маніпуляцій [2].

Ії̈ здійснюють шляхом дезінфекції та стерилізації всіх предметів, що контактують з раною або операційним полем. Асептика в хірургічному відділенні включає:

- підготовку кабінету (операційної);

- спеціальну обробку рук хірурга;

- дезінфекцію операційного поля;

- стерилізацію стоматологічних інструментів;

- стерилізацію перев'язувального матеріалу та білизни;

- стерилізацію шовного матеріалу;

- стерилізацію імплантованих тканин та речовин, що вводять у тканини хворого;

- дотримання особливих прийомів під час лікувальних маніпуляцій, що попереджують повітрянокрапельний шлях передачі інфекції;

- організацію роботи персоналу щодо здійснення спеціальних гігієнічних та організаційних заходів у хірургічному кабінеті.

Асептика складається з двох основних моментів: дезінфекції та стерилізації.

Дезінфекція - комплекс прийомів і методів, спрямованих на повне, часткове чи селективне знищення потенційно патогенних для людини мікроорганізмів та їх носіїв на об'єктах зовнішнього середовища з метою розриву шляхів передачі збудників інфекційних захворювань від джерел інфекції до сприйнятливих людей.

Стерилізація - процес повного знищення мікроорганізмів, включаючи їхні спорові форми, застосуванням фізичних і хімічних засобів впливу.

Технологічно процес стерилізації складається із таких етапів:

1) дезінфекції;

2) очистки інструментів від крові, жиру та бруду;

3) розкладання матеріалів у стерилізаторі;

4) власне стерилізації;

5) сушки;

6) контролю за стерилізацією;

7) зберігання простерилізованого інструментарію та матеріалу [2].

Для забезпечення асептичної роботи необхідно добре знати можливі джерела потрапляння мікробів у рану. Це два шляхи: екзогенний і ендогенний.

Екзогенною вважають інфекцію, що потрапляє в рану із зовнішнього середовища: з повітря (повітряна), з бризками слини (крапельна), з предметів дотичних до рани (контактна) і з предметів, що залишаються в рані: шовного матеріалу, дренажів, протезів тощо (імплантантна).

Ендогенною вважають інфекцію, що існує всередині організму або на його покривах (шкіра, дихальні шляхи, шлунково-кишковий тракт тощо). Ця інфекція може потрапити в рану шляхом безпосереднього занесення або по лімфатичних чи кровоносних судинах. Для профілактики ендогенної інфекції необхідне своєчасне ії виявлення і подальша санація (лікування тонзилітів, синуситів, піодермії і т. д.) [3].

Профілактика повітряної та крапельної інфекції. Бактеріологічні дослідження показали, що в навколишнє середовище з дихальних шляхів і шкірних покривів виділяється за 1 хв від 10 до 100 тис. мікробів. Операційний блок відокремлюють від хірургічних відділень. Для створення умовної асептики при проведенні операцій необхідно здійснювати суворе і чітке зонування приміщень:

- стерильна зона (операційна, стерилізаційна);

- зона суворого режиму (передопераційна, наркозна, апаратна);

- зона обмеженого режиму (інструментально-матеріальна, лабораторія термінових аналізів, кімната медичних сестер, хірургів, протокольна); 
- зона загальнолікарняного режиму.

Прибирання операційних здійснюють тільки вологим способом із застосуванням розчинів, уякі входять різні фізіологічні розчини (1 \% розчин хлораміну, 3 \% перекису водню з 0,5 \% розчином мийних засобів, 0,2 \% дезоксону - 1, 2 \% дихлор - 1 та ін.) [3].

Види прибирання:

1. Попереднє - проводять щодня вранці перед початком операцій. Протирають антисептиками підлогу, стіни, підвіконня тощо, щоб прибрати пил, який осів за ніч.

2. Поточне - в процесі операції прибирають предмети, що впали на підлогу, витирають підлогу, забруднену кров'ю та іншими рідинами. Після завершення операції обробляють операційний стіл, підлогу навколо столу і забруднені меблі.

3. Завершальне - після закінчення операційного дня. Ретельно миють підлогу, стіни (на висоту людського зросту), протирають меблі.

4. Генеральне - миття операційної один раз у 7-10 днів гарячою водою з милом і антисептиками, включаючи стелю. Протирають меблі та апаратуру [3].

Перед початком та після завершення робочої зміни, а також упродовж дня у випадках «макроскопічно видимого забруднення рук», проводять гігієнічну обробку рук (звичайне миття рук водою зі звичайним милом). 3 метою зниження числа мікроорганізмів, що перебувають на руках, проводять гігієнічну антисептику (обробка рук шляхом втирання спиртового антисептика в шкіру рук для ліквідації транзиторних мікроорганізмів). Її бажано проводити перед і після кожного контакту з пацієнтом, після кожного забруднення, перед входом в операційну. Антисептик (не менше 3 мл) вливають в заглиблення сухої долоні та енергійно втирають в шкіру рук та зап'ястя протягом 30 с. Упродовж всього часу втирання шкіру підтримують зволоженою антисептиком, тому кількість порцій засобу, який втирають, суворо не регламентують. Останню порцію засобу втирають до повного його висихання. Витирання рук не допустиме. При виконанні обробки рук враховують наявність «критичних» іï ділянок, які недостатньо змочують антисептиком: великі пальці, кінчики пальців, зони між пальцями, нігті, валики біля нігтів та піднігтьові зони. Найретельніше обробляють поверхні великого пальця та кінчики пальців, оскільки на них зосереджена найбільша кількість бактерій. Перевагу надають препаратам, що мають нейтральну реакцію та містять поверхневоактивні речовини (стериліум, декасепт).
При виконанні інвазивних маніпуляцій (збір крові, підключення систем для внутрішньовенного введення) одягають рукавички. Хірургічна антисептика рук передбачає втирання антисептика в шкіру (без застосування води) для ліквідації транзиторних мікроорганізмів та максимального зниження кількості резидентних мікроорганізмів. Використовують 0,5 \% водно-спиртовий розчин хлоргексидину біглюконат (руки 2 рази по 3 хв обробляють тампонами), 70 \% етанол і 60 \% пропан (руки 1-2 хв протирають тампонами), стериліум (композиція поверхнево-активних речовин і пропанолу), що втирають в шкіру 3 рази по 3 мл упродовж 30 с. Дія зберігається 3 год.

Антисептик наносять на руки порціями (1,5-3,0 мл) і втирають в шкіру в кисті, передпліччя і ліктьового згину протягом часу, вказаного розробником. Першу порцію антисептика наносять на сухі руки. Протягом всього часу втирання шкіру підтримують вологою, тому кількість порцій засобу, який втирають, та його об'єм суворо не регламентують. Під час процедури особливу увагу приділяють обробці кистей рук, яку потрібно проводити за європейським стандартом (EN 1500). Кожну стадію обробки повторюють не менше 5 разів. Найретельніше обробляють поверхні великого пальця та кінчики пальців, оскільки на них зосереджена найбільша кількість бактерій. Останню порцію антисептика втирають до його повного висихання.

Хірургічне миття рук - це процедура миття рук із використанням спеціального антимікробного засобу, для ліквідації транзиторних мікроорганізмів та максимально можливого зниження чисельності резидентних мікроорганізмів. Найчастіше використовують первомур (перекис водню 30-33 \% - 171 мл, мурашина кислота 85 \% - 81 мл або $100 \%$ - 69 мл, вода - до 10 л). Руки миють 1 хв. Робочий розчин зберігають не більше 1 доби і використовують для обробки рук 10-15 осіб. Діюча речовина - надмурашина кислота (утворюється при окисненні мурашиної кислоти перекисом водню). Миття включає декілька етапів:

І етап - миття рук із милом під проточною водою (1 хв без щіток, що зменшує травматизацію шкіри, зберігає її властивості). Краще застосовувати теплу воду (знежирення і вимивання мікробів із крипт, проток, їх відкриття перед обробкою дезінфікуючими засобами, що полегшує проникнення останніх). Послідовність обробки окремих частин рук - див. хірургічна антисептика рук та стандартна методика обробки кистей рук антисептиком. 
II етап - витирання на сухо стерильною серветкою.

III етап - обробка кистей і передпліч деззасобами (в такій же послідовності). Після обробки заборонено опускати кисті нижче рівня грудей, торкатися нестерильних предметів, струшувати залишки дезрозчину. Кисті потрібно тримати вище передпліччя (залишки дезрозчину мають стікати з кисті на передпліччя).

IV етап - витирання на сухо стерильною серветкою з дотриманням правил асептики, починаючи з кінчиків пальців, одягання стерильного халата і стерильних рукавичок.

Метод Спасокукоцького-Кочергіна та інші, що передбачають використання щіток, нашатирного та етилового спирту, йоду, в даний час не використовують у зв'язку з ушкодженням шкіри рук і ненадійністю.

Необхідність застосовувати рукавички зумовлена двома обставинами: обробка рук не забезпечує їх стерильності («захист пацієнта від медперсоналу»), існує ризик інфікування персоналу від хворого («захист медперсоналу від пацієнта»).

\section{СПИСОК ЛІТЕРАТУРИ}

1. Electronic resourse. Mode access : http://medcoledg. ucoz.ru/Hirurgia_s/profilaktika_medichnoji_sestriantiseptika.pdf

2. Electronic resourse. Mode access : http://www.umsa. edu.ua/kafhome/dithirstom/lecture/Aseptica_ukr.pdf
Стерильні рукавички надягають тільки на сухі руки. Після одягання їх ретельно протирають спиртом. Під час операції потрібно уважно стежити за цілісністю рукавичок і при пошкодженні негайно їх замінити. При заміні рукавичок руку потрібно протерти спиртом або обмити розчином первомуру.

За 20-30 хв після одягання рукавичок за рахунок випаровування з поверхні шкіри під рукавичками збирається волога («рукавичковий сік»), що містить багато мікробів. При пошкодженні рукавички ця рідина і аутофлора шкіри потрапляють до рани. Це підтверджує необхідність попередньої обробки рук. В рану також може потрапляти і речовина (пудра), якою були оброблені рукавички для збереження властивостей матеріалу.

Висновки. Асептика - це метод профілактики хірургічної інфекції, а антисептика - один із методів лікування останньої. В обох методах використовують як фізичні, так і хімічні засоби.Тобто асептика і антисептика $є$ базовими правилами організації та роботи відділень хірургічного профілю.

3. Electronic resourse. Mode access : http://intranet.tdmu. edu.ua/

4. Electronic resourse. Mode access : http://pidruchniki. com/73522/meditsina/zberezhennya_sterilnosti

Отримано 16.08.18 